\title{
A Critical Review of Project Implementation Strategy of the Southern African Development Community (SADC) Secretariat (2011-2014)
}

\author{
Maalila Malambo \\ School of Finance and Professional Studies, Botswana Accountancy College, Gaborone, Botswana \\ Email:maalilam@bac.ac.bw
}

How to cite this paper: Malambo, M. (2021). A Critical Review of Project Implementation Strategy of the Southern African Development Community (SADC) Secretariat (2011-2014). Journal of Financial Risk Management, 10, 298-305.

https://doi.org/10.4236/jfrm.2021.103017

Received: June 27, 2021

Accepted: September 3, 2021

Published: September 6, 2021

Copyright $\odot 2021$ by author(s) and Scientific Research Publishing Inc. This work is licensed under the Creative Commons Attribution-NonCommercial International License (CC BY-NC 4.0). http://creativecommons.org/licenses/by-nc/4.0/ (c) (i) (5) Open Access

\begin{abstract}
The objective of this research is to critically review the strategy for project implementation of the Southern African Development Community (SADC) Secretariat for the period 2011-2014. The study sought to critically analyze the constraints faced by the Secretariat to finalize and implement projects that would not have been completed. Since the formation of SADC in 1980, there has been little progress in this area. A sample of sixty-six (66) staff members composed of the directors and those directly involved in project management were drawn from a total population of five hundred (500) employees. Primary data was obtained through questionnaires and interviews and data from respondents was used to arrive at conclusions. To ensure the reliability and validity of conclusions and findings, the data collected was purely based on the research objectives in line with the research topic. In addition, literature read, from various sources, eliminated any chance of bias from one author. The research ascertained that since 1980, the SADC Secretariat has not fully met its strategic project implementation objectives. Despite several approved projects and policies and strategies in place, it was discovered that these projects were not successfully. Furthermore, funds are distributed late and there is lots of bureaucracy resulting in delayed implementations. The study also revealed that most member counties are not fully committed to the overall strategic road map of the organization. The research reached the conclusion that, to enable SADC successfully to achieve its objectives, the process of implementing projects must be underpinned by appropriate policies of implementation, and institutional frameworks, which gives conducive environment for these strategic process drivers.
\end{abstract}

\section{Keywords}

Risk Management, Strategies, Implementation, Project Management, Project 
Monitoring, Risk Analysis and Evaluation

\section{Introduction and Background}

SADC is a regional body made up of fifteen (15) Southern African countries, namely Angola, Botswana, Democratic Republic of Congo, Lesotho, Madagascar, Malawi, Mauritius, Mozambique, Namibia, Seychelles, South Africa, Eswatini, United Republic of Tanzania, Zambia and Zimbabwe (SADC, 2012a). One of the bloc's key objectives since its inception in 1980 was to be achieved economic growth and development in the region (SADC, 2012b). This was to be achieved by ways of coordinating its member countries, political alliance, and coordinating poverty alleviating projects/programmes within the SADC. Through the SADC Resource Mobilisation Strategy, the regional body has made frantic efforts to make resources available for the sustainable implementation of regional programmes (SADC, 2012a). The SADC project implementation strategy and mobilizing resourcefunction, is centralized at the SADC Secretariat in Gaborone, Botswana (SADC, 2012b).

\section{Statement of the Problem}

Despite sizeable financial resources that the regional bloc SADC has managed to mobilize as explained above, there has been slow finalization and implementation of projects by the SADC Secretariat (Nkani, 2015). The foregoing was buttressed in a newspaper article by the former President R.G Mugabe of Zimbabwe who was the bloc's Chairman in May 2015 (Nkani, 2015). This was also confirmed on SADC's website (http://sadc.com/) pointing out that the institution is not implementing projects well compared with other regional bodies like the Common Market for Eastern and Southern Africa (COMESA) and Economic Community of West African States (ECOWAS) (SADC, 2012b). In addition, the construction of the SADC headquarters in Gaborone, Botswana was also delayed in 2007, the project was supposed to start in March, but however, it ended up starting in October 2007 (Mokgoabone, 2007). This paper seeks to explore possible factors that could be causing SADC low pace for implementing agreed projects as well as assessing the ability of the current strategies to facilitate in project management. It is envisaged that the knowledge and information derived from this research will be used to enhance and improve Project strategic implementation not only within the SADC Secretariat but also by other similar regional bodies and member countries.

\section{Literature Review}

\subsection{Contextualisation of Project and Strategy Implementation}

(Maylor, 2005) defines projects as vehicles for strategic project implementation. The term "implementation" is identical to terms like "execution" and "actualisation 
of goals" which are frequently used in management (Wysocki \& McGary, 2003). During project implementation, the Project manager is tasked with initiating, managing, and controlling all the activities of the project team to ensure delivery of the end product/service. (Pinto \& Slevin, n.d.) acknowledge that successfully implementing a project is a difficult and complex task. This is further made worse by constant change taking place during the project life, in an environment full of risk and uncertainty (Bricknell et al., 2012; Maylor, 2005).

(Wysocki \& Mc-Gary, 2003: p. 3) define a project as a sequence of unique, complex, and connected activities with one goal that must be completed by a specific time, budget, and specification. From these definitions, it can be deduced that a project follows several stages, has an objective, and has limited resources. These stages are termed the project life cycle and are namely, initiation, plan, execution, control, and closure (Bricknell et al., 2012).

Having put a project strategic plan in place, the next step, is to ensure make that it works (Hrebiniak, 2006). (Hrebiniak, 2006) further argues that formulating a strategy is a difficult task and making the strategy work is even more challenging. As such, it can be argued that this process of implementation should be given as much attention as possible. Otherwise, all the resources committed to the project will be of no relevancy if the implementation is haphazard.

(Kotler \& Armstrong, 2008) define Strategy implementation as a process of converting management plans into action and ensuring that these plans are attained. (Harrington, 2006) defines strategy implementation as an iterative process of implementing strategies, policies, programmes and action plans that allow a firm to utilise its resources and maximise opportunities in the competitive environment. (Raimondi et al., 2012) concurs with Harrington's definition and goes on to further state that defining the implementation strategy is a critical planning process activity.

(Lock, 2013) is of the view that it is critical to monitor and evaluate every project to ensure it fits within the strategy before implementation. (Lock, 2013) outlines that it is importance that managers must as well evaluate projects to ensure the strategies, fit in within the organizational objectives and see how they relate to the key capability requirements, that is, the financial and other constraints. In addressing the above, if the projects are not properly evaluated, then the resources should not be committed to such projects.

\subsection{Constraints in Project Strategy Implementation}

Planning big projects is not an easy task for any project manager, let alone making the plan work, that is implementation (Hrebiniak, 2006). To monitor and ensure a project is still on schedule, project evaluating has also proved to be a challenge and sometimes quite problematic (Heeks, 2002; Currie, 1995). (Noble, 1999) noted that even after an organization has crafted a strategy, several challenges are still experienced during the implementation process. Good and effective strategies may still fail to give desired results if they are not properly implemented. The most common constraints in project implementation are (Goel, 2009; Maruapula, 2008). 
- Budgetary/Financial contracts

- Lack/Inadequate planning

- Staffing grievances

- Government bureaucracy

- Lack of project activity monitoring

- Political expediency and vested interests

- Too many similar projects under way at one time

\subsubsection{Budgetary/Financial Contracts}

Lack of financial resources and poor financial management are arguably the major courses of project failure (Wysocki, 2003). Every project that is operated is usually undertaken against a detailed budget. (Wysocki, 2003) indicated that most projects face resource limitations in the form of financial, human and machines. (Raimondi et al., 2012) in their study of Regional Operational Programmes (ROP) in Europe discovered that the implementation of plans is often restricted by financial inadequacies. This seems to be a shared constraint between Europe and developing countries in Africa. However, there are cases where funds are made available and still the projects fail. It is not unusual in a developing country that after the budget has been approved and agreements have been signed, projects still fail. It can be noted that, even where funds are available, planning is essential. Financial constraints have to be identified by planning and every effort made to acquire enough funds before resources can be committed to a project. Funds can be obtained from aid agencies, grants and bank loans if need be.

\subsubsection{Inadequate Planning}

(Goel, 2009) argues that difficulties in implementation are usually caused by lack of project planning at initial stages. In the Information Technology industry, they use the term “G.I.G.O”, that is Garbage In Garbage Out, meaning that if a poor plan is rolled into action, poor results will be attained regardless of how stringent the implementation process is. This means that the strength of an implementation process lies in the original plan. If the planning process is wholesome, then the implementation phase will be wholesome as well. Inadequate planning usually leads to problems in schedule, cost overruns and ultimately poor performance. Planning, implementation, and evaluation need to be viewed as a critical process in project management, as these complement each other. This implies that before a plan can be concluded, a Project manager should have the implementation plan and evaluation plan in place.

\subsubsection{Staffing Matters}

Lack of properly trained personnel is another cause of incomplete and failed projects. It is a fact that without the properly trained technical staff, a project will fail. (Lock, 2013) indicated that when a project has been authorized, it is handed over to the contractor or project team. (Maruapula, 2008) emphasizes that in addition to training, staff who were originally involved in the project initiation should be the 
same allowed to implement projects, which is not the case with most projects as this point is usually overlooked in project implementation.

\subsubsection{Government/Organisational Bureaucracy}

(Maruapula, 2008) notes that although it is important to have checks and balances, these at times bring problems that tend usually bring negative impacts on project implementation processes and its results. He further noted that most of the Government systems tend to be more focused on processes than the actual project implementation. Furthermore, even after project approval, the disbursement of project funds and other relates resources, takes too long to be availed thus ultimately delaying the actual in project implementation.

\subsubsection{Lack of Project Activity Monitoring}

The implementation process should be subjected to constant monitoring and evaluation to ensure corrective measures are taken early and improvements identified for future project design (Goel, 2009). Without an effective project monitoring and evaluation, projects would always behind schedule. Stakeholder's' expectations need to be monitored and controlled as-well as managing potential risk. The Earned Value Management (EVM) is one tool and technique frequently to monitor and control the performance of projects. The EVM model provides organizations with a mechanism to assist monitor and control costs and scheduling of projects.

\subsubsection{Political Expediency and Vested Interests}

(Maruapula, 2008) argues that Members of Parliament often use projects for their political mileage. Generally, most politicians are not really concerned about the project per se, but about driving their political agenda. Mostly when politicians get the votes, the projects become a thing of the past. Also, in some cases the politicians can divert funds allocated to a particular project or other projects where they have an interest.

\subsubsection{Too Many Similar Projects under Way at One Time}

According to (Goel, 2009), for quick and successful implementation of projects once a project has been approved, no new similar projects should be undertaken unless there is no option. This ensures that funds and other project related resources earmarked for the project are not diverted elsewhere. In addition, no material project variations should be allowed unless where it is very necessary.

The main reason for considering the above constraints is so that alternative course of action, counter measures and proper strategies for managing projects can be adopted.

\section{Research Methodology}

The sample survey approach was used for this research study. Questionnaires and personal interviews were administered to gather information as part of data collection. The research used convenient sampling and only available SADC Secretariat 
employees were given questionnaires. Out of a total of five hundred SADC Secretariat employees, a sample of seventy employees comprising of Directors and personnel that were involved in project execution, was used by way of a simple random sampling method.

\section{Research Results}

The following were noted as some of the factors that stifle effective project implementation in SADC.

\subsection{Funding}

It emerged that lack of financial resources is still a major cause of project failure. In addition, the late distribution of funds is also another contributing factor to poor project implementation.

\subsection{Availability of Skilled Personal}

Lack of trained personnel also emerged as one of the challenges that hindered the SADC Secretariat to successfully implement the agreed and approved projects. There is a gap between the planning and execution of the projects. Normally, people who are involved in the planning process are different from the implementers of the projects.

\subsection{Political Intervention}

The research findings found no relationship between Parliamentarians' political interests and the implementation of projects as had been propounded by (Maruapula, 2008). SADC undertakes its own projects without much political interference.

\subsection{Commitment by Member States}

The lack of commitment by member states was also noted as one of the contributing factors to non-projects implemented by the SADC secretariat. However, this is evident enough that commitment in project implementation with the SADC region has been a problem.

\subsection{Organisational Bureaucracy}

Processes such as funds approval were viewed as some of the reasons why projects are not implemented as agreed. It was gathered that funds delay to be released after approval.

\section{Recommendations}

\subsection{Public, Private Partnerships (PPPs)}

Member states need to eliminate anti-competitive monopolies and encourage open market forces to prevail so that the private sector could have access to business opportunities through (PPPs). Such partnerships are aimed at reducing depen- 
dency on governments within the SADC region for the provision of various services, goods, and public entities.

\subsection{Enhancing the Oversight and Project Implementing Institutions}

The SADC Secretariat should put in place an effective oversight and implementation framework if infrastructural projects in the region are to be coordinated well and cost effectively. It is, therefore, paramount that the region urgently thinks of creating appropriate institutions or better still strengthen the existing ones to discharge the mandates of the SADC secretariat in an effective and efficient manner.

\subsection{Review of the Evaluation System}

The Rural Infrastructure Development Master Plan of 2012 of the SADC secretariat put in place a robust monitoring system aimed at making follow ups and progress reporting criteria on infrastructural development and other related issues. The monitoring system in place should be reviewed periodically to address any project implementation lapses at all levels within the region.

\subsection{Resource Needs versus Capacity}

Project feasibility study should be done before any project funding is done to ascertain the financial requirements required for each project. This would ensure that the available would be used to complete projects.

\subsection{Implementation of the User Pays Principle}

The region should consider migrating to the cost reflective tariffs across industry with a view to attracting direct foreign investment. This can be done by requesting beneficiaries of regional projects to pay for part of the facilities of projects they are using or benefiting from.

\section{Conclusion}

There are a lot of lessons that can be learnt from the case of the SADC Secretariat. There is a great need to engage all stakeholders at the early stages of the project life cycle. Although SADC has put in place many policies and strategies, little attention has been given to implementation hence the need for policies to be in place to guide the implementation processes. Furthermore, member state commitment towards the strategic goal needs to be improved.

\section{Conflicts of Interest}

The author declares no conflicts of interest regarding the publication of this paper.

\section{References}

Bricknell, L., Franser, J., Goldman, G., Kara, M., Labuschagne, L., Maree, M., McGregor, A., \& Radford, A. (2012). Project Management in Perspective. Oxford University Press. 
Currie, W. (1995). Management Strategy for IT: An International Perspective.

Goel, B. B. (2009). Project Management Principles \& Techniques. Deep Publications.

Harrington, J. H. (2006). Resource Management Excellence: The Art of Excelling in Resource and Assets Management. Paton Press.

Heeks, R. (2002). Implementing and Managing E-Government: An International Text (1st ed.). SAGE Publication.

Hrebiniak, L. G. (2006). Making Strategy Work: Leading Effective Execution and Change (2nd ed.). Pearson Education.

Kotler, P., \& Armstrong, G. (2008). Principles of Marketing. Pearson.

Lock, D. (2013). Project Management (10th ed.). Gower.

Maruapula, O. B. (2008). Facilitative Project Management: Contextual Interrogation beyond Construction. Pentagon Publishers.

Maylor, H. (2005). Project Management (3rd ed.). Prentice Hall.

Mokgoabone, K. (2007). Construction of SADC HQ Begins. Mmegi.

http://www.mmegi.bw/index.php?sid=4\&aid=34\&dir=2007/december/Friday14

Nkani, P. (2015, May 22). SADC Members Not Committed to Regional Integration. The Guardian, p. 3.

Noble, D. F. (1999). The Religion of Technology: The Divinity of Man and the Spirit Invention. Penguin.

Pinto, J. K., \& Slevin, D. P. (n.d). Critical Success Factors in Effective Project Implementation.

http://www.researchgate.net/profile/Jeffrey Pinto/publication/267559698 20. Critical Succ ess Factors in Effective Project implementation*/links/54d218800cf25ba0f04256a7.pdf

Raimondi, A., Chesani, F., \& Woods, T. (2012). Deliverable D 2.2: "Impacts, Constraints, Objectives and Implementation Strategies in Regional Planning: General Aspects”. http://cordis.europa.eu/docs/projects/cnect/7/288147/080/deliverables/001-D22.pdf

SADC (2012a). Southern African Development Community (SADC): Towards a Common Future. http://www.sadc.int

SADC (2012b). SADC Resource Mobilization Strategy. http://www.sadc.int/files/1913/7234/8601/SADC RMS English Booklet.pdf

Wysocki, R. K., \& McGary, R. (2003). Effective Project Management: Traditional, Adaptive \& Extreme (3rd ed.). Wiley.

\section{Website}

https://www.sadc.int/files/7513/5293/3530/Regional Infrastructure Development Maste r Plan Executive Summary.pdf 